\title{
A thermostable bacterial lytic polysaccharide monooxygenase with high operational stability in a wide temperature range
}

\author{
Tina Rise Tuveng ${ }^{\dagger}$, Marianne Slang Jensen ${ }^{\dagger}$, Lasse Fredriksen, Gustav Vaaje-Kolstad, Vincent G. H. Eijsink ${ }^{*}$ (1)
} and Zarah Forsberg ${ }^{*}$

\begin{abstract}
Background: Lytic polysaccharide monooxygenases (LPMOs) are oxidative, copper-dependent enzymes that function as powerful tools in the turnover of various biomasses, including lignocellulosic plant biomass. While LPMOs are considered to be of great importance for biorefineries, little is known about industrial relevant properties such as the ability to operate at high temperatures. Here, we describe a thermostable, cellulose-active LPMO from a high-temperature compost metagenome (called mgLPMO10).

Results: MgLPMO10 was found to have the highest apparent melting temperature $\left(83^{\circ} \mathrm{C}\right)$ reported for an $L P M O$ to date, and is catalytically active up to temperatures of at least $80^{\circ} \mathrm{C}$. Generally, mgLPMO10 showed good activity and operational stability over a wide temperature range. The LPMO boosted cellulose saccharification by recombinantly produced GH48 and GH6 cellobiohydrolases derived from the same metagenome, albeit to a minor extent. Cellulose saccharification studies with a commercial cellulase cocktail (Celluclast ${ }^{\circledR}$ ) showed that the performance of this thermostable bacterial LPMO is comparable with that of a frequently utilized fungal LPMO from Thermoascus aurantiacus (TaLPMO9A).

Conclusions: The high activity and operational stability of mgLPMO10 are of both fundamental and applied interest. The ability of mgLPMO10 to perform oxidative cleavage of cellulose at $80^{\circ} \mathrm{C}$ and the clear synergy with Celluclast ${ }^{\circledR}$ make this enzyme an interesting candidate in the development of thermostable enzyme cocktails for use in lignocellulosic biorefineries.
\end{abstract}

Keywords: LPMO, Thermostability, Cellulose, Synergy

\section{Background}

Lignocellulosic biomass (i.e., plant-based biomass) is the most abundant source of renewable carbon on Earth [1] and its major component is cellulose, a linear polymer of glucose units joined by $\beta-1,4$-glycosidic bonds [2]. Individual cellulose chains commonly arrange into crystalline

\footnotetext{
*Correspondence: vincent.eijsink@nmbu.no; zarah.forsberg@nmbu.no

${ }^{\dagger}$ Tina Rise Tuveng and Marianne Slang Jensen contributed equally to this article

Faculty of Chemistry, Biotechnology and Food Science, NMBU-Norwegian University of Life Sciences, Aas, Norway
}

fibrils consisting of multiple chains that are stabilized by extensive hydrogen bonding, and this assembly makes cellulose highly resistant to both chemical and microbial degradation [3, 4]. However, certain microorganisms have evolved to overcome this recalcitrance by producing specialized enzymes, and these may be employed in industrial bioprocessing for the sake of generating renewable energy and bulk commodities $[5,6]$.

Cellulose-degrading enzymes include cellulases that cleave glycosidic bonds using a hydrolytic mechanism, which are further classified as endoglucanases or exo-acting cellobiohydrolases (CBHs). While endoglucanases are 
thought to attack randomly in amorphous (i.e., loosely packed) cellulose by engulfing the cellulose chain in a catalytic cleft, cellobiohydrolases attack the cellulose from accessible chain ends using a tunnel-shaped active site [7]. The turnover of cellulose by cellulases is hampered by the fact that the enzymes cannot easily access the crystalline surfaces of the cellulose fibrils [8].

Enzymes called lytic polysaccharide monooxygenases (LPMOs) employ a powerful oxidative mechanism to cleave glycosidic bonds within crystalline regions of densely packed polysaccharides such as cellulose and chitin [8-10]. This mode of action is enabled by a flat substrate-binding surface with a surface-exposed active site. The ability of LPMOs to disrupt crystalline cellulose fibrils, thereby granting the hydrolytic enzymes access to binding sites in parts of the substrate that they would otherwise struggle to reach $[9,11]$, makes LPMO activity crucial in the development of industrial bioprocessing technologies $[12,13]$.

The catalytic function of LPMOs was discovered in 2010 [9] and today these enzymes are classified as auxiliary activities (AA) in the carbohydrate-active enzymes database (http://www.cazy.org [14]). Currently, LPMOs are categorized in CAZy families AA9-11 and AA13-16 on the basis of sequence similarity, and may be active on cellulose, various types of hemicelluloses, chitin, starch and/or oligosaccharides [10, 15]. Thus, LPMOs hold an important role in the Earth's carbon cycle.

LPMOs hydroxylate either the $\mathrm{C} 1$ or $\mathrm{C} 4$ carbon of the scissile glycosidic bond in cellulose [9, 16, 17], whereas some are less regioselective and produce a mixture of $\mathrm{C} 1$ and C4-oxidized products. Oxidation of the $\mathrm{C} 1$ carbon results in the formation of $1,5-\delta$-lactones that are spontaneously hydrated to the more stable aldonic acid form, while oxidation of the $\mathrm{C} 4$ carbon produces 4-ketoaldoses that are hydrated to their corresponding gemdiol form [18]. Like cellulases, LPMOs may be associated with one or more carbohydrate-binding modules (CBMs), often connected via a flexible linker [19].

Two highly conserved histidines located in the center of the flat substrate-binding surface constitute the catalytic core of LPMOs. The histidines coordinate a single copper ion, which must be reduced from the $\mathrm{Cu}(\mathrm{II})$ to the $\mathrm{Cu}(\mathrm{I})$ state before the LPMO can initiate oxidative cleavage [17]. Notably, reduced LPMOs are known to be prone to oxidative damage when exposed to $\mathrm{O}_{2}$ or $\mathrm{H}_{2} \mathrm{O}_{2}$ in the absence of a proper substrate [20-22].

LPMO catalysis has generally been thought to be strictly dependent on molecular oxygen and a reductant that delivers two electrons and two protons for each catalytic cycle $[9,23,24]$. However, recent studies on LPMOs belonging to families AA9 and AA10, have shown that $\mathrm{H}_{2} \mathrm{O}_{2}$ can drive LPMO reactions, and that these reactions are orders of magnitude faster than $\mathrm{O}_{2}$-driven reactions [20, 25-29]. The peroxygenase driven reaction only requires sub-stoichiometric amounts of reductant for an initial, "priming", reduction of the LPMO, after which the enzyme can catalyze multiple reactions. Notably, under the conditions normally used in LPMO reactions, $\mathrm{H}_{2} \mathrm{O}_{2}$ will be formed either by non-productive oxidase activity of reduced LPMO molecules that are not bound to the substrate $[18,30]$ or by reactions involving dioxygen and the reductant.

Although LPMOs have been intensely studied since their discovery in 2010 [10, 15, 22, 31], and even though they are considered to be of great importance for industrial biorefining $[12,13]$, little is known about industrially relevant properties such as activity and stability at higher temperatures. Thermostability is a commonly desired trait for enzymes employed in biorefineries because stable enzymes last longer and because it is often considered favorable to run processes at higher temperatures, for example to improve reactant solubility and reduce the risk of microbial contamination [32]. Naturally occurring thermostable enzymes can be discovered by bioprospecting of high-temperature environments where biomass turnover occurs in Nature. To date, only a few studies have aimed at engineering thermal stability of LPMOs $[33,34]$.

The present study describes the characterization of a thermostable bacterial AA10 LPMO with a C-terminal CBM2 domain. The gene encoding the enzyme has previously been identified as the only LPMO overexpressed in a metatranscriptome originating from rice straw that was inoculated with compost and incubated at high temperature [35]. We have compared the properties of this LPMO, named mgLPMO10 (mg, for metagenome), with the properties of a similar two-domain mesophilic LPMO from Streptomyces coelicolor, ScLPMO10C [36], and we have assessed its potential to boost the activity of various cellulases.

\section{Results}

\section{Verification of activity and thermal stability}

The full-length LPMO (mgLPMO10; residues 32-363) and the catalytic domain (mgLPMO10 ${ }^{\mathrm{CD}}$; residues 32-223) were expressed and purified to electrophoretic homogeneity. The yield for mgLPMO10 was typically around 12-15 mg purified protein per liter of E. coli and 4-5 mg per liter E. coli culture for mgLPMO10 ${ }^{\mathrm{CD}}$. We also purified ScLPMO10C, a C1-oxidizing cellulose-active LPMO [37], which was included in the experiments to enable comparison of mgLPMO10 to a mesophilic homologue. The overall sequence identity between full-length ScLPMO10C and mgLPMO10 is 56\%; $62 \%$ between the catalytic AA10 domains and 
$47 \%$ between the CBM2 domains (Fig. 1). The LPMO and CBM2 domains are separated by a proline- and threonine-rich linker that is seven residues longer in mgLPMO10. The closest homologue of mgLPMO10, as identified by a BLAST search, is an uncharacterized putative LPMO from Micromonospora sp. HM5-17, which shares $85 \%$ and $95 \%$ sequence identity, for the full-length protein and the catalytic domain, respectively, suggesting mgLPMO10 to be of Actinomycetales origin. The oxidative activity of mgLPMO10 on cellulose was initially verified using PASC and Avicel under standard conditions (e.g., $1 \mathrm{mM}$ ascorbic acid, aerobic conditions). The MALDI-ToF product profile showed peaks characteristic for oxidized cello-oligosaccharides (black spectrum), including peaks representing the sodium salt of the sodium adduct of the aldonic acids $(\mathrm{m} / z+38$ species), which (in combination with very low levels of the $m / z-2$ species) is diagnostic for C1-oxidation (Fig. 2a). The regioselectivity was confirmed by HPEAC-PAD analysis of product mixtures, which showed only C1-oxidized products (Fig. 2b).

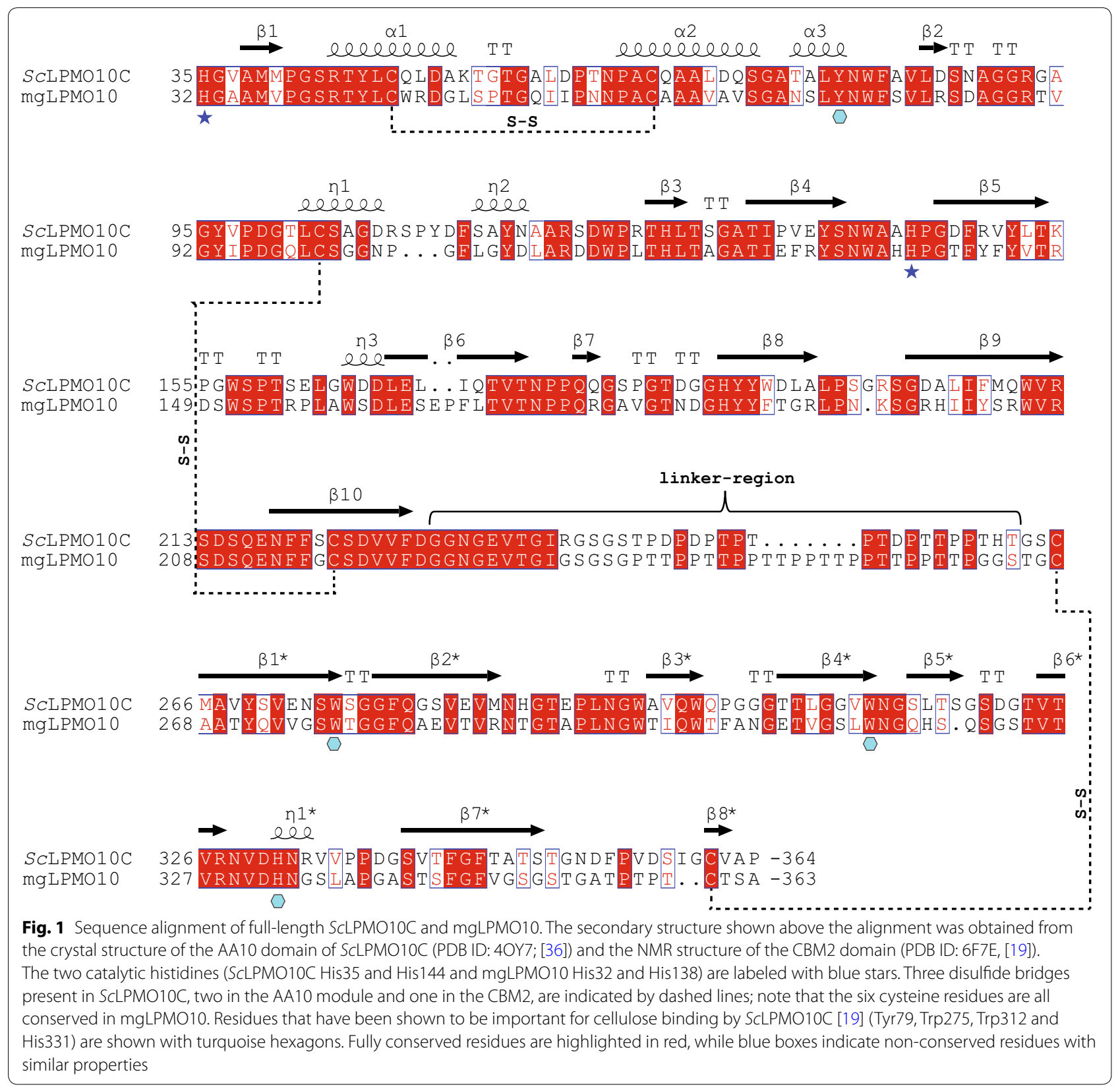



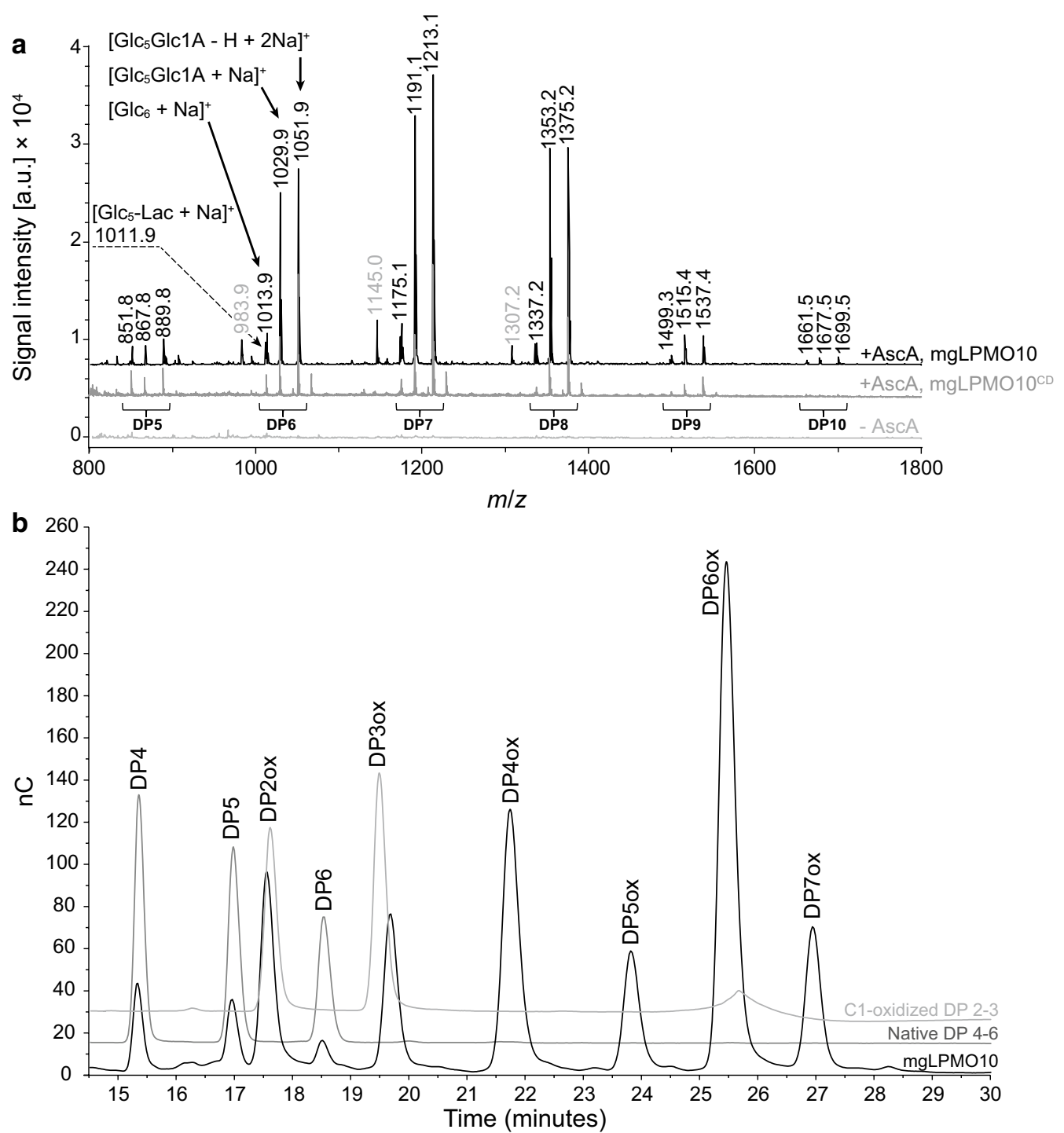

Fig. 2 Verification of $L P M O$ activity. Full-length mgLPMO10 or mgLPMO10 ${ }^{C D}$ was incubated with $5 \mathrm{~g} / \mathrm{L}$ PASC or $10 \mathrm{~g} / \mathrm{L}$ Avicel in $50 \mathrm{mM}$ sodium phosphate buffer ( $\mathrm{pH}$ 6.0) supplemented with $1 \mathrm{mM}$ ascorbic acid at $60^{\circ} \mathrm{C}$ for $24 \mathrm{~h}$. The supernatant was subjected to analysis by MALDI-ToF (PASC samples) for both mgLPMO10 variants (a) and HPAEC-PAD (Avicel samples) for full-length mgLPMO10 (b). The peaks of the hexamer cluster are denoted by arrows and show the sodium adduct of native cellohexaose $\left[\mathrm{Glc}_{6}+\mathrm{Na}\right]^{+}$and two larger peaks that represent sodium adducts of C1-oxidized cellohexaose (aldonic acid), namely $\left[\mathrm{Glc}_{5} \mathrm{Glc} 1 \mathrm{~A}+\mathrm{Na}\right]^{+}$and $\left[\mathrm{Gl}_{5} \mathrm{Glc} 1 \mathrm{~A}-\mathrm{H}+2 \mathrm{Na}\right]^{+}$. Note that the 1,5- $\delta$-lactone $(\mathrm{m} / \mathrm{z}-2 \mathrm{species})$ is also visible at 1011.9, labeled $\left[\mathrm{Gl}_{5} \text { - Lac }+\mathrm{Na}\right]^{+}$. Of note, the spectrum shows a series of minor signals $(984,1145,1307$, grey-labeled masses) differing by one glucose $(162 \mathrm{~m} / \mathrm{z})$ that represent products of unknown nature. No products were observed for a reaction with only PASC and AscA, and neither for a reaction with PASC and the LPMO but in absence of AsCA (grey spectrum). The HPAEC chromatogram for mgLPMO10 shows similar product profile as the well-characterized SCLPMO10C with C1-oxidized cello-oligomers ranging from DP 2-7. No C4-oxidized products, that have longer retention times [18], were detected

Differential scanning calorimetry (DSC; Fig. 3) showed that the $T_{\mathrm{m} \text { (app) }}$ of the full-length mgLPMO10, is approximately $83{ }^{\circ} \mathrm{C}$, and that truncation of the linker and the CBM2 $\left(\left[T_{\mathrm{m} \text { (app) }}\right] 76^{\circ} \mathrm{C}\right)$ as well as removal of the copper cofactor $\left(T_{\mathrm{m}(\mathrm{app})} 73^{\circ} \mathrm{C}\right)$ have negative effects on the thermal stability. All unfolding events showed a single transition and unfolding was irreversible in all cases.

\section{The effect of temperature on LPMO activity}

Monitoring of product formation over time at varying incubation temperatures (Fig. 4) showed a trade-off between activity and enzyme inactivation and revealed a clear difference between mgLPMO10 and ScLPMO10C. For mgLPMO10, the initial activity increased with temperature all the way up to $80{ }^{\circ} \mathrm{C}$ (the highest tested 


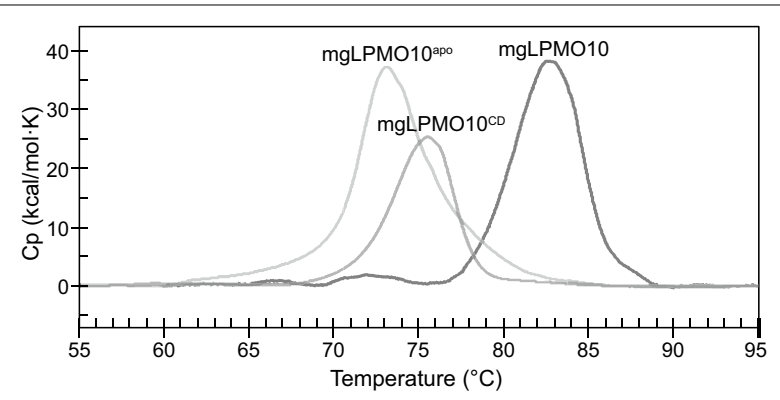

Fig. 3 Thermal unfolding of mgLPMO10. The apparent melting temperatures ( $\left.T_{\mathrm{m}(\mathrm{app})}\right)$ were determined by differential scanning calorimetry (DSC) by heating the full-length mgLPMO10-holo (approximately $0.4 \mathrm{~g} / \mathrm{L}$ ) at $1{ }^{\circ} \mathrm{C} / \mathrm{min}$ from $25^{\circ} \mathrm{C}$ to $100^{\circ} \mathrm{C}$ in $50 \mathrm{mM}$ sodium phosphate buffer ( $\mathrm{pH}$ 6.0). The experiment was repeated for the apo version of the protein $\left(\mathrm{mgLPMO} 10^{\mathrm{apo}}\right)$ and the holo catalytic domain (mgLPMO10 ${ }^{\mathrm{CD}}$ )

temperature). Only at $80^{\circ} \mathrm{C}$, the product formation curve showed clear signs of enzyme inactivation, with product levels stabilizing already after approximately $20 \mathrm{~min}$ at a level (approximately $350 \mu \mathrm{M}$ solubilized product) that is lower than the highest observed product level (approximately $500 \mu \mathrm{M}$ in the reaction carried out at $70{ }^{\circ} \mathrm{C}$ ). In contrast, ScLPMO10C showed clear signs of enzyme inactivation in the reaction carried out at $70{ }^{\circ} \mathrm{C}$ (Fig. 4), which is about $6{ }^{\circ} \mathrm{C}$ above its apparent melting temperature ([38]; Table 1), whereas no products were observed in the reaction at $80^{\circ} \mathrm{C}$.

The product formation curves for mgLPMO10 in Fig. 4 show that the reactions slow down after 60-120 min of incubation, also when using incubation temperatures that are well below $T_{\mathrm{m}(\mathrm{app})}$. For $S c \mathrm{LPMO} 10 \mathrm{C}$ the product formation levels out already after 20-30 min. To evaluate the causes of the reduction in product formation, an experiment was carried out where extra reactants (i.e., substrate, enzyme and/or reductant) were added after reaching the endpoint of the reaction (Fig. 5). The results showed that the enzymes became inactivated, since the
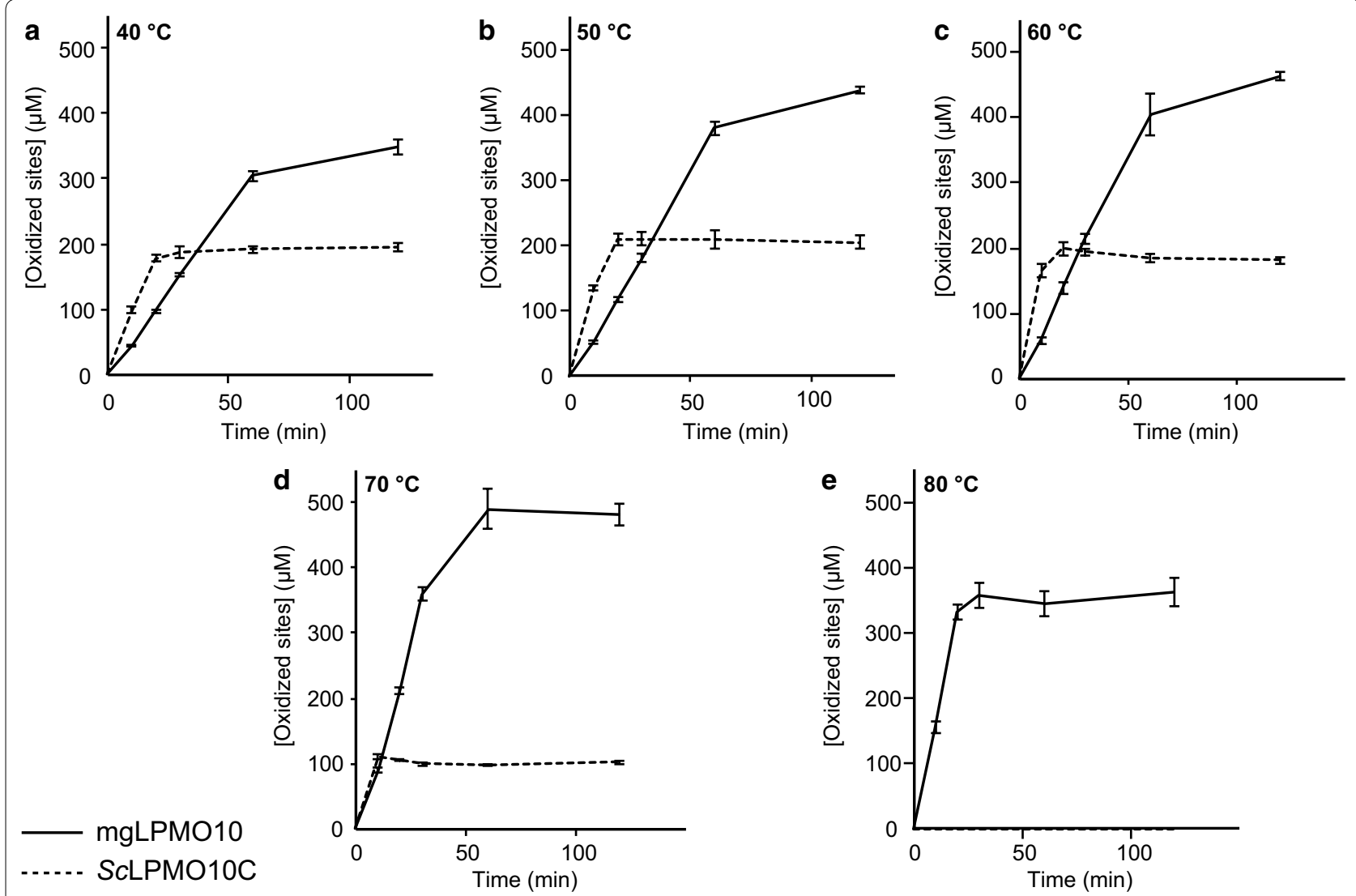

Fig. 4 Activity of mgLPMO10 and SCLPMO10C at various temperatures. a-e show progress curves for copper-saturated mgLPMO10 (solid curves) and SCLPMO10C (dashed curves) at 40,50,60, 70 and $80^{\circ} \mathrm{C}$, respectively. The reactions were carried out with $1 \mu \mathrm{M} \mathrm{LPMO}$ and $10 \mathrm{~g} / \mathrm{L}$ Avicel in $50 \mathrm{mM}$ sodium phosphate buffer $\mathrm{pH}$ 6.0. The reactions were pre-incubated for $10 \mathrm{~min}$ at various temperatures before $1 \mathrm{mM}$ ascorbic acid was added to start the LPMO reaction. The reactions were carried out in Eppendorf Thermomixers at 800 rpm and samples were taken and filtered at $10,20,30,60$ and $120 \mathrm{~min}$. The solubilized products were degraded to oxidized dimers and trimers by incubation with $0.5 \mu \mathrm{M}$ mgCel6 A prior to product quantification. The reaction with $\mathrm{SCLPMO10C}$ at $80^{\circ} \mathrm{C}(\mathbf{e})$ did not yield any oxidized products. The error bars show $\pm \mathrm{SD}(n=3)$ 
Table 1 Reported $T_{m(a p p)}$ values for AA9 and AA10 LPMOs in the literature

\begin{tabular}{|c|c|c|c|c|c|c|}
\hline Enzyme (and additives) $^{a}$ & $T_{\text {m(app) }}\left({ }^{\circ} \mathrm{C}\right)$ & pH (buffer) & Method & Domains & $\begin{array}{l}\text { Reversible/ } \\
\text { irreversible } \\
\text { folding }\end{array}$ & References \\
\hline mgLPMO10-holo & 83.0 & 6.0 (phosphate) & DSC & AA10-CBM2 & Irreversible & This study \\
\hline mgLPMO10-аро & 73.0 & 6.0 (phosphate) & DSC & AA10-CBM2 & Irreversible & This study \\
\hline mgLPMO10 ${ }^{\mathrm{CD}}$-holo & 76.0 & 6.0 (phosphate) & DSC & AA10 & Irreversible & This study \\
\hline ScLPMO10C-holo & 64.1 & 6.0 (phosphate) & DSF & AA10-CBM2 & ND & Jensen et al. [38] \\
\hline SmLPMO10A-holo & 71.2 & 6.0 (phosphate) & DSF & AA10 & ND & Jensen et al. [38] \\
\hline SmLPMO10A-holo & 74.4 & 5.0 (acetate) & DSC & AA10 & Reversible & Sugimoto et al. [45] \\
\hline SmLPMO10A-apo & 65.6 & 5.0 (acetate) & DSC & AA10 & Reversible & Sugimoto et al. [45] \\
\hline SmLPMO10A & 70.3 & 8.0 (Tris-HCl) & ITF & $\mathrm{AA} 10$ & $\mathrm{ND}$ & Vaaje-Kolstad et al. [46] \\
\hline EfLPMO10A & 72.0 & 8.0 (Tris-HCl) & ITF & AA10 & ND & Vaaje-Kolstad et al. [46] \\
\hline BaLPMO10A-holo & 65.0 & 5.0 (acetate) & DSF & $\mathrm{AA} 10$ & ND & Hemsworth et al. [47] \\
\hline BaLPMO10A-apo & 46.0 & 5.0 (acetate) & DSF & AA10 & ND & Hemsworth et al. [47] \\
\hline BaLPMO10A + EDTA & 48.0 & 5.0 (acetate) & DSF & AA10 & ND & Hemsworth et al. [47] \\
\hline BaLPMO10A-Zn'2+ & 52.0 & 5.0 (acetate) & DSF & $\mathrm{AA} 10$ & ND & Hemsworth et al. [47] \\
\hline BaLPMO10A-Ni ${ }^{2+}$ & 53.0 & 5.0 (acetate) & DSF & AA10 & ND & Hemsworth et al. [47] \\
\hline BaLPMO10A-Mn ${ }^{2+}$ & 46.0 & 5.0 (acetate) & DSF & AA10 & ND & Hemsworth et al. [47] \\
\hline TaLPMO9A-holo & 74.3 & 7.0 (MOPS) & ITF & AA9 & Reversible & Singh et al. [48] \\
\hline TaLPMO9A-apo & 65.2 & 7.0 (MOPS) & ITF & AA9 & Reversible & Singh et al. [48] \\
\hline TaLPMO9A-holo (deglycosylated) & 67.9 & 7.0 (phosphate) & ITF & AA9 & Reversible & Singh et al. [48] \\
\hline MtLPMO9B & $75.0^{\mathrm{b}}$ & 7.0 (phosphate) & $C D$ & AA9-CBM1 & Irreversible & Frommhagen et al. [49] \\
\hline MtLPMO9D & $68.0^{b}$ & 7.0 (phosphate) & $C D$ & AA9 & Irreversible & Frommhagen et al. [49] \\
\hline NcLPMO9C-holo & 61.5 & 6.0 (phosphate) & DSF & AA9-CBM1 & ND & Kracher et al. [44] ${ }^{c}$ \\
\hline NcLPMO9C-holo & 44.0 & 4.0 (acetate) & DSF & AA9-CBM1 & ND & Kracher et al. [44] \\
\hline NcLPMO9C-holo & 34.7 & 4.0 (citrate) & DSF & AA9-CBM1 & ND & Kracher et al. [44] \\
\hline NcLPMO9C-apo (+ EDTA) & 52.7 & 6.0 (phosphate) & DSF & AA9-CBM1 & ND & Kracher et al. [44] \\
\hline NcLPMO9C-holo + AscA & 48.8 & 6.0 (phosphate) & DSF & AA9-CBM1 & ND & Kracher et al. [44] \\
\hline NcLPMO9C-holo + xyloglucan & 61.4 & 6.0 (phosphate) & DSF & AA9-CBM1 & ND & Kracher et al. [44] \\
\hline $\begin{array}{l}\text { NcLPMO9C-holo + xyloglu- } \\
\text { can + AscA }\end{array}$ & 60.4 & 6.0 (phosphate) & DSF & AA9-CBM1 & ND & Kracher et al. [44] \\
\hline NCLPMO9C & 63.0 & 6.0 (phosphate) & DSC & AA9-CBM1 & ND & Kittl et al. [30] \\
\hline NCLPMO9J & 66.9 & 6.0 (phosphate) & DSC & AA9-CBM1 & ND & Kittl et al. [30] \\
\hline NCLPMO9F & 68.9 & 6.0 (phosphate) & DSC & AA9 & ND & Kittl et al. [30] \\
\hline NCLPMO9E & 67.9 & 6.0 (phosphate) & DSC & AA9-CBM1 & ND & Kittl et al. [30] \\
\hline PVLPMO9A-holo & 59.6 & 7.0 (Polybuffer 96, GE Healthcare) & DSC & AA9-C-term ${ }^{d}$ & ND & Semenova et al. [50] \\
\hline PVLPMO9A-apo & 49.9 & 7.0 (Polybuffer 96, GE Healthcare) & DSC & AA9-C-term ${ }^{d}$ & ND & Semenova et al. [50] \\
\hline
\end{tabular}

Ligands or other molecules present during the determination of the apparent melting temperature are provided with the enzyme names

ND not detected, DSC differential scanning calorimetry, DSF differential scanning fluorimetry, ITF intrinsic Trp fluorescence, CD circular dichroism

a The term "holo" refers to the enzyme with copper bound, while "apo" refers to the metal free enzyme; the presence of other metals and/or substrates is indicated. If nothing is written by the enzyme name, the experiment was performed with unknown copper content

b Temperatures estimated based on CD diagrams in Frommhagen et al. [49]

c The table only shows a selection of stability data presented in the study by Kracher et al. [44]

${ }^{d}$ C-terminal peptide of unknown function

addition of more substrate and/or ascorbic acid alone did not lead to the release of more products, whereas the addition of fresh enzyme did. Thus, even at temperatures that are low (e.g., $\left.50{ }^{\circ} \mathrm{C}\right)$ relative to the $T_{\text {m(app) }}\left(83{ }^{\circ} \mathrm{C}\right)$, enzyme inactivation limits the reaction, as is commonly observed for LPMOs [22]. It is worth noting that the addition of extra ascorbic acid next to fresh enzyme was not favorable, which could be due to ascorbic acid promoting rapid inactivation of the added enzyme. In the 


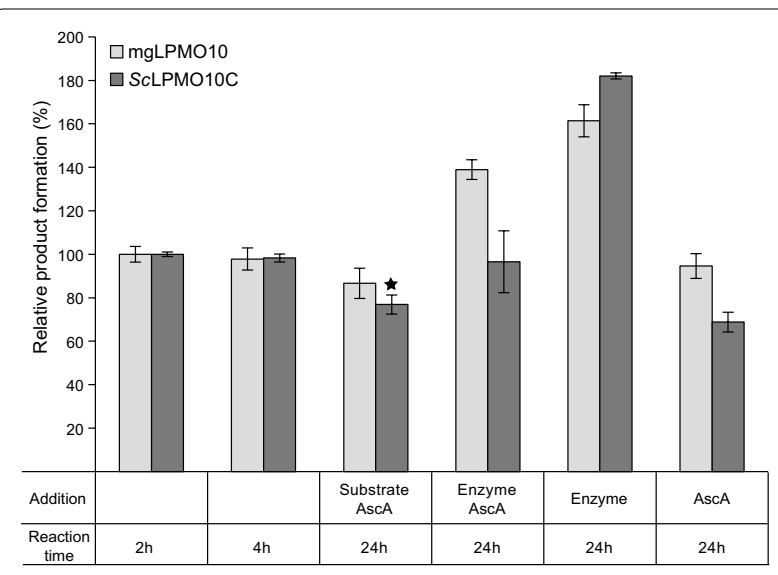

Fig. 5 Probing early inactivation of mgLPMO10 and SCLPMO10C. A "mother reaction" containing $10 \mathrm{~g} / \mathrm{L}$ Avicel in $50 \mathrm{mM}$ sodium phosphate pH 6.0, 1 MM mgLPMO10 (light grey) or SCLPMO10C (dark grey) and $1 \mathrm{mM} \mathrm{AscA}$ was incubated at $50^{\circ} \mathrm{C}$ until product formation was stable (the left two sets of bars show product formation in the "mother reaction" after 2 and $4 \mathrm{~h}$ ). The "mother reaction" was subsequently split into four new reactions to which fresh reactants were added, as indicated in the figure, to the same final concentration as in the starting "mother reaction". The reactions were then incubated for another $20 \mathrm{~h}$ before separating the soluble fraction from the insoluble particles. The solubilized products were degraded to oxidized dimers and trimers by incubation with $1 \mu \mathrm{M}$ mgCel6A prior to product quantification. All reactions were carried out in triplicates, and error bars show $\pm \mathrm{SD}(n=3)$, except for the reaction marked with a star where $n=2$

case of mgLPMO10, an identical experiment was done at $60{ }^{\circ} \mathrm{C}$, with similar results.

\section{The effect of mgLPMO10 on the efficiency of Celluclast ${ }^{\circledR}$ and individual cellulases in cellulose degradation}

Full-length mgLPMO10 was tested in a spiking experiment with the commercial cellulase cocktail Celluclast ${ }^{\circledR}$, which has little LPMO activity [39]. In the experiment, 5 or $15 \%$ of the standard enzyme cocktail, consisting of Celluclast ${ }^{\circledR}$ and a $\beta$-glucosidase in a 10:1 ratio, was replaced by mgLPMO10, or by BSA as a control. Figure 6 shows that replacing parts of the Celluclast $^{\circledR}$ cocktail with mgLPMO10 led to clearly higher saccharification yields. The positive effect of the LPMO became only visible in the later phase of the reaction, suggesting that LPMO activity is particularly important for saccharification of the more recalcitrant fraction of the cellulose substrate. Interestingly, the synergistic effect was the same for the experiments with $5 \%$ and $15 \%$ mgLPMO10, indicating that only a small fraction of LPMO is needed to boost the efficiency of the cellulase cocktail. When 15\% BSA was added instead of the

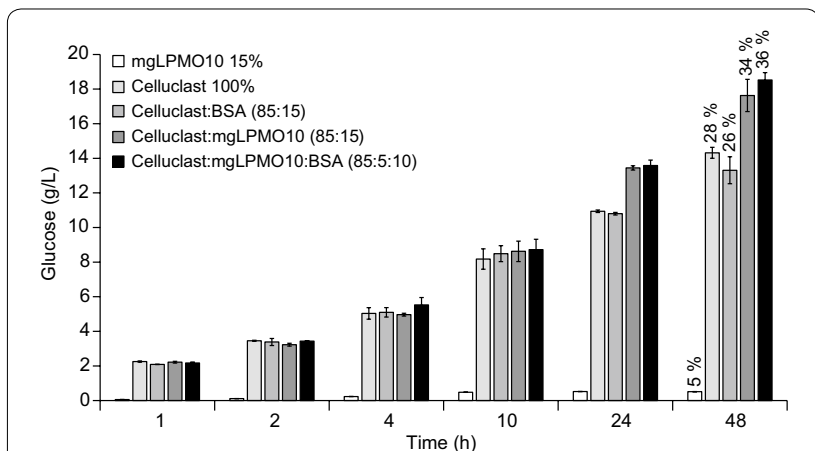

Fig. 6 Effect of mgLPMO10 on saccharification of Avicel by Celluclast ${ }^{\circledR}$. Reaction mixtures were incubated at $50{ }^{\circ} \mathrm{C}$ and contained $50 \mathrm{~g} /$ Avicel in $50 \mathrm{mM}$ sodium phosphate buffer $\mathrm{pH}$ 6.0. The total protein dosage was $4 \mathrm{mg} / \mathrm{g}$ glucan, with $100 \%$ of Celluclast ${ }^{\circledR}$ (i.e., a mixture of Celluclast ${ }^{\circledR}$ and $\beta$-glucosidase in a ratio of 10:1), or Celluclast ${ }^{\circledR}$ and mgLPMO10 in different ratios. Samples from the reaction with $\mathrm{mgLPMO} 10$ alone were subjected to postdigestion with a mixture of Celluclast ${ }^{\circledR}$ and $\beta$-glucosidase prior to product analysis. BSA was used as control. The numbers over the $48 \mathrm{~h}$ bars show the total glucan conversion (\% of maximum). All reactions contained $1 \mathrm{mM}$ AscA and were run in triplicates with standard deviations indicated in the figure

LPMO, a negative effect was observed at $48 \mathrm{~h}$, but the effect was negligible in the beginning of the reaction.

To further explore the impact of mgLPMO10 on cellulase activity two putative $\mathrm{CBHs}$ derived from the same metagenome were expressed, namely mgCel6B and $\mathrm{mgCel} 48 \mathrm{~A}$, where the latter is known to be coexpressed with mgLPMO10 [35]. MgCel48A has an $\mathrm{N}$-terminal CBM2 domain followed by a domain of unknown function with immunoglobulin-like fold and a catalytic GH48 domain. The domain structure of mgCel48A is similar to that of the well-studied reducing-end directed CBH TfCel48A from Thermobifida fusca [40], with 58\% overall sequence identity. MgCel6B has an N-terminal CBM2 followed by the GH6 catalytic domain. Its domain structure and sequence (64\% identity) are similar to that of $T f C e l 6 \mathrm{~B}$, which is thought to act from the non-reducing end [41, 42]. Product profiles for the two cellulases (Figure 7a, b) show that the by far dominant product generated from Avicel is cellobiose. This dominance, and the concurrent low production of glucose and cellotriose (which neither of the enzymes can cleave; Fig. 7a, b) is indicative of processive action [43]. Studies of product formation upon combining the LPMO and each of the cellulases (Fig. 7c, d) showed no synergistic effect, and even a minor antagonistic effect, in the initial phase of the reaction, whereas over time synergistic effects were detected for both CBH-LPMO combinations. 

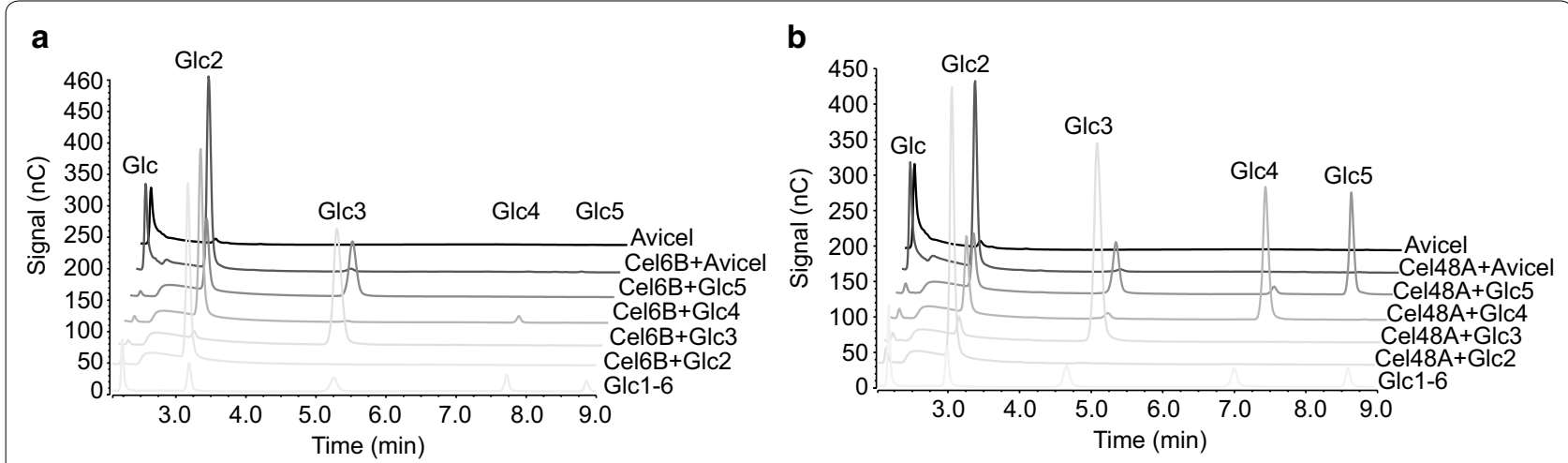

C

d
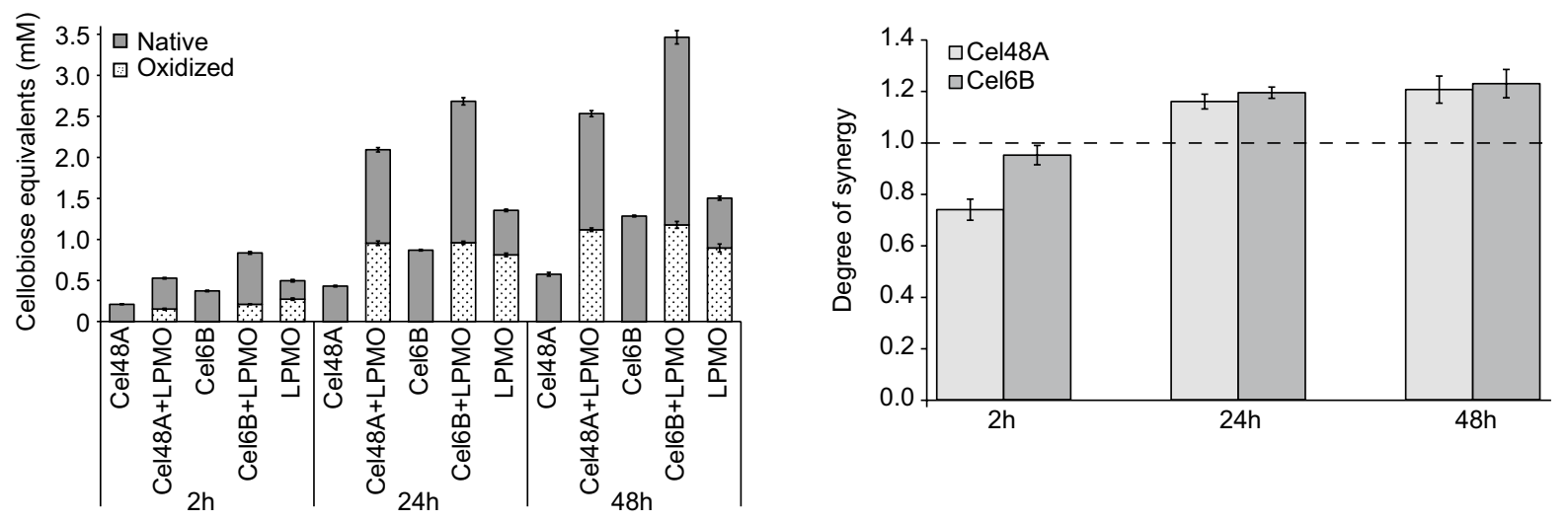

Fig. 7 Synergy between mgLPMO10 and mgCBHs and product profiles for the $\mathrm{mgCBHs}$. $\mathbf{a}$, $\mathbf{b}$ show product profiles after degradation of cello-oligosaccharides and Avicel for mgCel6B and mgCel48A, respectively. The enzymes $(0.5 \mu \mathrm{M})$ were incubated with $0.1 \mathrm{~g} / \mathrm{L}$ cello-oligosaccharide (DP 2-5) in $50 \mathrm{mM}$ sodium phosphate $\mathrm{pH} 6.0$ at $60^{\circ} \mathrm{C}$. The chromatograms for the oligomeric substrates are from HPEAC-PAD analysis of samples taken after $10 \mathrm{~min}$ reaction time for mgCel6B and $30 \mathrm{~min}$ reaction time for mgCel48A. The chromatograms for Avicel degradation are the $2 \mathrm{~h}$ samples in the experiment shown in c. Note the background signal for glucose in the Avicel-only control and the fact that glucose production by the enzymes was very low. Panel $\mathbf{c}$ shows product formation over time during degradation of Avicel by various enzyme combinations. Reaction mixtures were incubated at $60^{\circ} \mathrm{C}$ and contained $10 \mathrm{~g} / \mathrm{L}$ Avicel in $50 \mathrm{mM}$ sodium phosphate buffer $\mathrm{pH}$ 6.0, $1 \mathrm{mM}$ AscA and $1 \mu \mathrm{M}$ of each enzyme. Prior to quantification of native and oxidized solubilized products by HPEAC-PAD, these products were treated with mgCel6A to simplify the product mixture, and the amounts of the various products were converted to cellobiose equivalents. Error bars represent standard deviations with $n=3$. Panel $\mathbf{d}$ shows the degree of synergy calculated from data in $\mathbf{c}$. Error bars represent propagated standard deviations from $\mathbf{c}$

\section{Discussion}

In this study, we describe a thermostable cellulose C1-oxidizing LPMO with an apparent melting temperature of $83{ }^{\circ} \mathrm{C}$, which, to our knowledge, is the highest $\mathrm{T}_{\mathrm{m}(\text { app) }}$ reported for an LPMO (Table 1). Indeed, this novel LPMO was capable of cellulose conversion at temperatures up to $80{ }^{\circ} \mathrm{C}$, in contrast to mesostable LPMO10C from S. coelicolor (ScLPMO10C), which showed impaired activity already at $70{ }^{\circ} \mathrm{C}$. Considering ScLPMO10C's apparent $\mathrm{T}_{\mathrm{m}}$ of $64{ }^{\circ} \mathrm{C}$ [38], it may seem surprising that the enzyme works at all at $70{ }^{\circ} \mathrm{C}$, but this may be explained by stabilizing effects of substrate binding, as has been observed for fungal NcLPMO9C in the presence of a xyloglucan substrate [44]. The effect of the CBM on the apparent melting temperature of mgLPMO10 is not easily explained. The linker between the CBM2 and the LPMO domain in ScLPMO10C is flexible and NMR studies have shown that the two domains move independently [19]. Thus, one might expect the catalytic domain and the CBM to act as separated units that fold and unfold independently. This could result in an unfolding curve with two transitions or with a more gradual "mixed" transition, as observed previously for a CBM-containing LPMO [49]. The unfolding curve of mgLPMO10 in Fig. 3 shows only a single transition, which indicates that the two domains do not unfold independently or that they unfold independently and have approximately the same melting temperature. Based on the present data it cannot be excluded that the two domains interact with each other in a manner that leads to stabilization. However, the decrease in stability upon removal of the linker and the CBM may also be due to the 
actual truncation, which may have created an unfavorable configuration at the C-terminus of the mgLPMO $10^{\mathrm{CD}}$ variant. Nevertheless, the $T_{\mathrm{m}(\mathrm{app})}$ of $\mathrm{mgLPMO} 10^{\mathrm{CD}}$ is higher than most other reported $\mathrm{T}_{\mathrm{m}}$ values for LPMOs (Table 1).

LPMO activity and stability under catalytic conditions depend on multiple factors that cannot easily be resolved. For example, we do not know the effects of elevated temperature on the reducing power and stability (reactivity with $\mathrm{O}_{2}$ ) of the reductant, nor on the various off-pathway reactions that the LPMO may engage in, in particular $\mathrm{H}_{2} \mathrm{O}_{2}$-generating oxidase activity (also called uncoupled reaction) and autocatalytic enzyme inactivation. Product yields and apparent enzyme inactivation do not necessarily reflect only thermal stability of the LPMOs or the general effect of temperature on enzyme catalysis. For example, increased LPMO activity at higher temperatures could reflect that $\mathrm{H}_{2} \mathrm{O}_{2}$ is generated at a faster rate as the temperature increases and may not necessarily reflect the catalytic rate of the LPMOs. Likewise, temperature effects on LPMO reduction and substrate binding, where the latter would affect both the oxidase activity of the LPMO and the sensitivity to autocatalytic inactivation, may partly underlie the temperature effects shown in Fig. 4. Of note, the concentrations of dissolved oxygen become less as temperature increases, but this does not seem to negatively affect initial LPMO activity. Despite these uncertainties, the present data leave no doubt that mgLPMO10 is a very stable LPMO that is active and stable at higher temperatures compared to its mesophilic counterparts, such as ScLPMO10C.

The observation that adding fresh enzymes to the reactions (Fig. 5) restored activity shows that enzyme inactivation limits the reactions. The observation that simultaneous addition of more AscA is unfavorable, especially for ScLPMO10C, was unexpected. This is not easily explained, but there are several side reactions that can occur and damage the enzyme [22]. In particular, addition of fresh AscA will lead to increased generation of $\mathrm{H}_{2} \mathrm{O}_{2}$. Increased formation of $\mathrm{H}_{2} \mathrm{O}_{2}$ would normally speed up the reaction, since $\mathrm{H}_{2} \mathrm{O}_{2}$ is a good co-substrate for LPMOs [20, 25, 28]. However, in this case, one could envisage a situation where too much $\mathrm{H}_{2} \mathrm{O}_{2}$ is produced due to excess AscA, which can damage the LPMO.

The observed enzyme stabilities for mgLPMO10 under catalytic conditions may reflect true folding stability (which is related to the $T_{\mathrm{m}(\mathrm{app})}$ ) and/or resistance against oxidative enzyme self-inactivation. It is well known that LPMOs may suffer from autocatalytic inactivation during catalysis [20-22] and this is also observed in the present study. The experiments depicted in Fig. 4 clearly show that maximum product levels (appr. $500 \mu \mathrm{M}$ ) obtained by mgLPMO10 at incubation temperatures that should not lead to enzyme unfolding are nevertheless limited by enzyme stability. Interestingly, the experiments of Fig. 5 also show that product yields were not limited by ascorbic acid. At a first glance this may seem strange since the product yields in this case (Fig. 4) indicate that as much as $50 \%$ of the $1 \mathrm{mM}$ added ascorbic acid has been converted to soluble oxidized products and since one would expect a considerable amount of additional oxidized products that are not soluble (e.g., oxidized sites on the polymeric substrate). However, it has been shown for ScLPMO10C, with a domain structure very similar to mgLPMO10 (Fig. 1) that in reactions with $10 \mathrm{~g} / \mathrm{L}$ Avicel, as used here, $>90 \%$ of the generated oxidized products are soluble [19]. Thus, it seems possible to generate $500 \mu \mathrm{M}$ soluble oxidized products without consuming the $1 \mathrm{mM}$ of reductant. The high fraction of soluble products is due to the fact that the CBM "immobilizes" the LPMO on the substrate surface, thus increasing the chance of the same polymer being cleaved twice, which is a prerequisite for generating a high fraction of soluble products (see Fig. 8 and Courtade et al. [19] for further discussion).

It is worth noting the difference in the approximate maximum product levels obtained in reactions with ScLPMO10C $(200 \mu \mathrm{M})$ and mgLPMO10 $(500 \mu \mathrm{M})$. This could indicate that the more thermally stable mgLPMO10 is also more resistant against oxidative damage (as also suggested by the effects of adding AscA in the experiments depicted in Fig. 5; see above). In this respect, it may be relevant that the linker connecting the catalytic domain and the CBM2 domain is seven residues longer in mgLPMO10. Studies on ScLPMO10C have shown that the catalytic domain and the CBM move independently

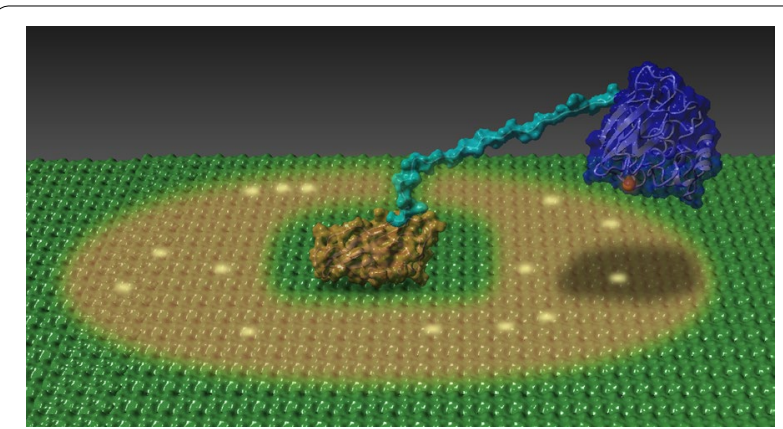

Fig. 8 Putative model for cellulose oxidation by SCLPMO10C based on NMR data. The CBM2 (orange) is docked on a cellulose surface (green) and tethered by a 30-residue linker (cyan) to the LPMO domain (blue). The brown color on the cellulose surface indicates an area of approximately $1300 \AA^{2}$, corresponding to approximately 300 glucose residues, that the LPMO domain can reach (rough estimate based on the radius of gyration of the ensemble of NMR structures). The yellow dots indicate potential sites of oxidation (random sites, for illustration purposes). This figure and its underlying data are from Courtade et al. [19] 
relative to each other, and that, due to the anchoring of the CBM2 on the cellulose surface, the freely moving but still restricted catalytic domain makes multiple cuts in nearby cellulose chains [19]. In the previous study of ScLPMO10C it was estimated that a cellulose-anchored catalytic domain could reach some $1300 \AA^{2}$ of cellulose surface (Fig. 8). An extension of the linker by seven residues, perhaps adopting an extended conformation, could considerably increase this sampling area, which would mean that mgLPMO10 can make more cuts per binding event and will, thus, spend less time in solution per number of cuts. Since reduced non-substrate-bound LPMOs are prone to inactivation through reactions with $\mathrm{O}_{2}$ or $\mathrm{H}_{2} \mathrm{O}_{2}$, spending less time in solution per number of cuts, or, phrased differently, staying in close proximity of the substrate for a longer time, will reduce oxidative damage and improve enzyme stability.

Combining mgLPMO10 with Celluclast ${ }^{\circledR} / \beta-$ glucosidase (Fig. 6) resulted in clearly improved saccharification yields in reactions with Avicel. The studies with individual enzymes (Fig. 7) showed that both mgCel48A, presumably acting from the reducing-end, and mgCel6B, presumably acting from the non-reducing-end, also act in synergy with mgLPMO10, however the synergy is only observed over time and the synergistic effect is minor. It is worth noting that oxidized products are a major part of the total product formation in these reactions. Limited synergistic effects between LPMOs and individual cellulases have been observed before. For example, earlier work $[51,52]$ has shown limited synergistic and even inhibitory effects upon combining a C1-oxidizing LPMO with the well-studied reducing-end active $\mathrm{CBH}$ from Trichoderma reesei ( $\operatorname{TrCel7A)}$. Further studies are needed to disclose the exact nature of the cellulaseLPMO interplay and to analyze to what extend and how the regioselectivity of the LPMO may affect the type of cellulase it synergizes with. Such studies should include multiple substrates and varying cellulase-LPMO ratios, since it is well known that the degree of cellulase-LPMO synergy is dependent in these factors [51-53].

The synergistic effects observed when adding mgLPMO10 to Celluclast ${ }^{\circledR}$ are encouraging. In a study by Müller et al. [39] it was reported that addition of various amounts of the well-studied $\mathrm{C} 1 / \mathrm{C} 4$ oxidizing fungal LPMO TaLPMO9A boosted the degradation of cellulose in steam exploded birch by Celluclast ${ }^{\circledR} / \beta$-glucosidase. In both this previous and the present study, the maximum improvement in saccharification yield amounted to $30-40 \%$, but to achieve this $15 \%$ LPMO needed to be added in the birch study, as opposed to only $5 \%$ (or less) in the present study with Avicel. While the two studies are not directly comparable, for example because of the different contents of reducing power (lignin in the birch experiment, $1 \mathrm{mM}$ ascorbic acid in the present study), it seems safe to conclude that mgLPMO10 is a powerful enzyme.

\section{Conclusion}

This study describes a thermostable LPMO, which, to our knowledge, possesses the highest melting temperature reported for an LPMO and which, uniquely, can carry out oxidative cleavage of cellulose at $80{ }^{\circ} \mathrm{C}$. The use of thermostable enzymes in biorefineries is of interest, since it is often preferable to run processes at high temperatures. MgLPMO10, with its profound boosting effect on cellulase efficiency that is comparable to the effect of commonly used fungal LPMOs, is a good candidate to be considered for the development of thermostable enzyme cocktails for industrial processing of lignocellulosic biomass.

\section{Methods \\ LPMO expression and purification}

The mgLPMO10-encoding gene originates from publicly available metagenome data accessible in the Joint Genome Institute IMG/M database (https://img.jgi.doe. gov/cgi-bin/m/main.cgi; IMG genome ID 2199352008). The microbial community was sampled from rice straw that had been inoculated with compost and incubated at $55{ }^{\circ} \mathrm{C}$. Metagenomic and metatranscriptomic analyses of this community are available [35, 54]. The $1092 \mathrm{bp}$ gene encoding mgLPMO10 (IMG/M gene ID 2200500718) was detected as overexpressed in the community ([35]; note that the LPMO is referred to as a CBM33 in this paper).

The mglpmo10 encoding gene (codon-optimized for Escherichia coli expression) was synthesized (GenScript, Piscataway, NJ, USA) and nucleotides 94-1089 (omitting the predicted 31 amino acid signal peptide sequence and the stop codon) were cloned in the pRSET B expression vector (Invitrogen, Carlsbad, California, USA), already containing the well-functioning signal sequence of $S m L P M O 10 A$ (also known as CBP21), following the protocol described by Forsberg et al. [36]. The forward primer employed to amplify and insert the gene into the PRESET B vector was 5'-CGC AACAGGCGAATGCCCACGGTGCGGCGATGGT$3^{\prime}$ and the reverse primer was $5^{\prime}$-CAGCCGGATCAA GCTTTTACGCGCTGGTGCAGGTC-3'. For production of the catalytic domain alone (mgLPMO10 ${ }^{\mathrm{CD}}$; nucleotide 94-669) the reverse primer 5'-CAGCCG GATCAAGCTTTTAATCAAAAACCACGTCGCT-3' was used instead. The underlined nucleotides represent an over-hang sequence with the pRSET B vector for fusing the gene in the pRSET B vector using the In-Fusion HD cloning kit (Clontech, Mountain View, California, 
USA), and the "TTA" sequence of the reverse primers (in bold) encodes a stop codon at the end of the LPMOencoding sequence. The gene sequences were verified by Sanger sequencing (Eurofins GATC, Cologne, Germany).

Chemically competent OneShot BL21 Star ${ }^{\mathrm{TM}}$ (DE3) E. coli cells (Invitrogen) harboring a pRSET B vector with an LPMO-encoding gene were used to inoculate $500 \mathrm{~mL}$ Terrific Broth (TB) supplemented with $100 \mu \mathrm{g} / \mathrm{mL}$ ampicillin, followed by incubation at $37^{\circ} \mathrm{C}$ for $20 \mathrm{~h}$ in a Harbinger system (Harbinger Biotechnology \& Engineering, Markham, Canada). Note that expression was driven by leakiness of the T7 promoter and that no inducer molecule was added. Cells were harvested by centrifugation at $5000 \times g$ for $15 \mathrm{~min}$ at $4{ }^{\circ} \mathrm{C}$ (Beckman Coulter Brea, California, USA), after which a periplasmic extract was prepared using an osmotic shock method [55].

Periplasmic extracts were filtered using $0.45 \mu \mathrm{m}$ syringe filters (Sarstedt, Nümbrecht, Germany) and adjusted to $50 \mathrm{mM}$ Tris- $\mathrm{HCl}(\mathrm{pH} 8.0)$ after which the proteins were purified by anion-exchange chromatography using an ÄKTA pure chromatography system (GE Healthcare, Chicago, USA) equipped with a 5-ml HiTrap DEAE FF column (GE Healthcare). As running buffer, $50 \mathrm{mM}$ Tris$\mathrm{HCl}(\mathrm{pH}$ 8.0) was used and proteins were eluted using a linear salt gradient $(0-500 \mathrm{mM} \mathrm{NaCl})$ over 60 column volumes. MgLPMO10 and mgLPMO10 ${ }^{\mathrm{CD}}$ displayed poor binding to the DEAE column, and thus mainly ended up in the flow through. Protein fractions were examined by SDS-PAGE (Bio-Rad, Hercules, California, USA) and relevant fractions (i.e., the flow through in this case) were concentrated to $1 \mathrm{~mL}$ using 10,000 MWCO (molecular weight cut-off) Vivaspin ultrafiltration tubes (Sartorius, Göttingen, Germany).

The concentrated protein samples were used in a second purification step by size exclusion chromatography, using a HiLoad 16/60 Superdex 75 column with a running buffer consisting of $50 \mathrm{mM}$ Tris- $\mathrm{HCl}(\mathrm{pH} \mathrm{8.0)}$ and $200 \mathrm{mM} \mathrm{NaCl}$. Fractions containing the LPMO, as determined by SDS-PAGE, were concentrated using 10,000 MWCO Vivaspin ultrafiltration tubes (Sartorius) with simultaneous buffer exchange to $20 \mathrm{mM}$ sodium phosphate buffer (pH 6.0).

Prior to use, purified enzymes were incubated for $30 \mathrm{~min}$ at room temperature with $\mathrm{Cu}(\mathrm{II}) \mathrm{SO}_{4}$ in a $1: 3$ molar ratio $\left(\mathrm{LPMO}: \mathrm{Cu}^{2+}\right)$ to generate copper-saturated LPMO. Apo enzyme was prepared by incubating the purified enzyme for $30 \mathrm{~min}$ at room temperature with ethylenediaminetetraacetic acid (EDTA) in a 1:10 molar ratio (LPMO:EDTA). A PD Midi-Trap G-25 column (GE Healthcare) was subsequently used to desalt and remove excess copper or EDTA from the enzyme.
Protein concentrations were determined by measuring $\mathrm{A}_{280}$ (absorbance at $280 \mathrm{~nm}$ ) in a spectrophotometer (Eppendorf Biophotometer, Eppendorf, Hamburg, Germany) and absorbances were converted to protein concentrations using theoretical extinction coefficients calculated with the ExPASy ProtParam tool (https://web. expasy.org/protparam/). The proteins were stored at $4{ }^{\circ} \mathrm{C}$ until further use.

\section{Production of additional enzymes}

Full-length ScLPMO10C and mgCel6A endoglucanase were produced and purified as described previously by Forsberg et al. [36] and Jensen et al. [56], respectively.

Genes encoding two putative cellobiohydrolases (CBHs), namely a 101.6 kDa GH48 (mgCel48A; IMG/M gene ID 2200387045; overexpressed together with mgLPMO10 in the thermophilic compost/rice straw community [35]) and a 61.4 kDa GH6 (mgCel6B; IMG/M gene ID 2200705178) from the same metagenome [54], were synthesized (GenScript, Piscataway, NJ, USA) and cloned for intracellular expression, without the native signal peptide and with a C-terminal His-tag according to the procedure described for the endoglucanase mgCel6A from the same metagenome [56]. The genes were cloned in the pNIC-CH expression vector using 5'-TTAAGA AGGAGATATACTATGGCACCGGCATGTGAAGTT ACCTAT- $3^{\prime}$ as the forward primer and $5^{\prime}$-AATGGT GGTGATGATGGTGCGCACCAATCAGACGATCATA ATCGGC- $3^{\prime}$ as reverse primer for mgCel48A. The forward primer for mgCel6B, was $5^{\prime}$-TTAAGAAGGAGA TATACTATGGCATTTGCAGCACCGGGTTGTAGC $-3^{\prime}$, while the reverse primer was $5^{\prime}$-AATGGTGGTGAT GATGGTGCGCCAGAGGCGGATATGCATTATCCAT $-3^{\prime}$. The underlined nucleotides represent an over-hang sequence for ligase-independent cloning in the pNIC expression vector. The proteins were produced and purified as described for mgCel6A by Jensen et al. [56].

\section{Commercial cellulase cocktail}

Celluclast $^{\circledR} 1.5 \mathrm{~L}$, a commercial cellulase cocktail with little LPMO activity [39] was provided by Novozymes (Bagsværd, Denmark). The Celluclast ${ }^{\circledR}$ cocktail was first mixed with a $\beta$-glucosidase, kindly supplied by Novozymes, in a 10:1 ratio (on a protein basis) to facilitate degradation of solubilized oligomers to the monomer (glucose).

\section{Substrates}

Evaluation of LPMO oxidative activity and saccharification experiments were carried out with the microcrystalline cellulosic substrate Avicel PH-101 (Sigma-Aldrich, Darmstadt, Germany) and phosphoric acid-swollen cellulose 
(PASC). PASC was prepared from Avicel PH-101 as described by [57]. Cello-oligosaccharides DP3-5 were purchased from Megazyme (Bray, Ireland). Glucose and cellobiose were purchased from Sigma-Aldrich.

\section{Apparent melting temperature}

A Nano-Differential Scanning Calorimeter III (Calorimetry Sciences Corporation, Lindon, USA) was used to determine $T_{\mathrm{m}(\mathrm{app})}$ of the mgLPMO10 variants. Approximately $0.4 \mathrm{mg} / \mathrm{mL}$ LPMO in $50 \mathrm{mM}$ sodium phosphate buffer $\mathrm{pH} 6.0$ (filtered and degassed) was heated from $25^{\circ} \mathrm{C}$ to $100{ }^{\circ} \mathrm{C}$ at $1{ }^{\circ} \mathrm{C} / \mathrm{min}$. Buffer baselines were recorded and subtracted from the protein scans. The data were analyzed with NanoAnalyze software (https://www. tainstruments.com).

\section{Activity assays}

Unless stated otherwise, reactions were performed in $50 \mathrm{mM}$ sodium phosphate buffer $(\mathrm{pH} 6.0)$ at $800 \mathrm{rpm}$ in an Eppendorf Thermomixer. All reactions were performed in triplicates using $2 \mathrm{~mL}$ micro tubes with screw cap and O-rings to avoid evaporation.

For the initial verification of oxidative cellulolytic activity, $1 \mu \mathrm{M}$ mgLPMO10 was incubated with $5 \mathrm{~g} / \mathrm{L}$ PASC or $10 \mathrm{~g} / \mathrm{L}$ Avicel in the presence of $1 \mathrm{mM}$ ascorbic acid (reductant) for $24 \mathrm{~h}$, at $60{ }^{\circ} \mathrm{C}$. The supernatant from PASC samples were analyzed by MALDI-ToF MS and the supernatant from Avicel samples were analyzed by HPAEC-PAD (see below) for detection of oxidized cellooligomers and determination of LPMO regioselectivity.

Degradation of Avicel $(10 \mathrm{~g} / \mathrm{L})$ was analyzed at different temperatures ranging from $40-80{ }^{\circ} \mathrm{C}$ using reaction mixtures containing $1 \mu \mathrm{M} \mathrm{LPMO}$ and $1 \mathrm{mM}$ ascorbic acid. Aliquots were withdrawn at selected time points and filtered $(0.45 \mu \mathrm{m})$ before being merged with an identical volume of a solution containing $2 \mu \mathrm{M}$ endoglucanase (mgCel6A; [56]) followed by static incubation overnight at $37^{\circ} \mathrm{C}$. As a result of this procedure, all solubilized oxidized products were converted to oxidized cellobiose and oxidized cellotriose, which simplified product quantification. The products were analyzed using HPAEC-PAD (see below).

Inactivation of mgLPMO10 and ScLPMO10C during cellulose degradation reactions was investigated by incubating $1 \mu \mathrm{M}$ enzyme with $10 \mathrm{~g} / \mathrm{L}$ Avicel and $1 \mathrm{mM}$ AscA at 50 or $60{ }^{\circ} \mathrm{C}$ until product formation stopped. The reactions were subsequently split into four new reactions and more AscA and substrate, AscA and enzyme, only enzyme, or only AscA was added to the same final concentration as in the original reaction. The reactions were further incubated for $20 \mathrm{~h}$ before separating the soluble fraction from the insoluble particles by filtration $(0.45 \mu \mathrm{m})$. The solubilized oxidized products were degraded to oxidized dimers and trimers by incubation with $1 \mu \mathrm{M}$ mgCel6A prior to product quantification, as described above, before product analysis by HPAEC-PAD (see below).

Degradation of individual cello-oligosaccharides by mgCel48A and mgCel6B was analyzed by incubating $0.1 \mathrm{~g} / \mathrm{L}$ cello-oligosaccharide $\left(\mathrm{Glc}_{2-5}\right)$ with $0.1 \mu \mathrm{M}$ enzyme in $50 \mathrm{mM}$ sodium phosphate $\mathrm{pH}$ 6.0. Reactions involving mgCel48A were supplemented with $1 \mathrm{mM}$ $\mathrm{CaCl}_{2}$ as this is known to stabilize other GH48s at high temperatures $[58,59]$. Samples taken after $30 \mathrm{~min}$ for $\mathrm{mgCel} 48 \mathrm{~A}$ and $10 \mathrm{~min}$ for $\mathrm{mgCel6B}$ were mixed with an equal volume of $0.2 \mathrm{M} \mathrm{NaOH}$ to stop the enzyme activity. Products were analyzed by HPEAC-PAD (see below).

\section{Synergy experiments}

Investigation of the synergistic relationship between mgLPMO10 and two putative cellobiohydrolases (CBHs; mgCel48A and mgCel6B) was performed using $10 \mathrm{~g} / \mathrm{L}$ Avicel as substrate, which was subjected to degradation by $1 \mu \mathrm{M}$ mgLPMO10 and/or $1 \mu \mathrm{M}$ of mgCel48A or mgCel6B. The reactions contained $50 \mathrm{mM}$ sodium phosphate buffer $(\mathrm{pH} 6.0)$, and $1 \mathrm{mM}$ ascorbic acid. Reactions involving mgCel48A were supplemented with $1 \mathrm{mM} \mathrm{CaCl}_{2}$. Samples were withdrawn after 2,24 , and $48 \mathrm{~h}$ of incubation at $60{ }^{\circ} \mathrm{C}$. After filtration $(0.45 \mu \mathrm{m})$ to remove insoluble substrate, the samples were mixed with and equal volume of $2 \mu \mathrm{M}$ mgCel6A and incubated statically at $37{ }^{\circ} \mathrm{C}$ overnight to simplify product quantification as described above. Native and oxidized cello-oligosaccharide products were analyzed using HPAEC-PAD (see below). Quantified products (cellobiose, GlcGlc1A, Glc ${ }_{2}$ Glc1A, as well as minor amounts of glucose and cellotriose) were converted to cellobiose equivalents.

The effect of mgLPMO10 on the saccharification efficiency of a mixture of Celluclast ${ }^{\circledR}$ and a $\beta$-glucosidase (see above) was investigated using $50 \mathrm{~g} / \mathrm{L}$ Avicel as substrate. The total protein load was $4 \mathrm{mg}$ per gram glucan (the glucan content of Avicel is 92.2\%; [39]). The reactions contained $50 \mathrm{mM}$ sodium phosphate, $\mathrm{pH} 6.0$, and $1 \mathrm{mM}$ ascorbic acid, and were incubated at $50^{\circ} \mathrm{C}$ (optimal temperature for Celluclast ${ }^{\circledR}$ ). Samples were withdrawn at selected timepoints and the supernatants were separated from the insoluble substrate by filtration over a $0.45 \mu \mathrm{m}$ microtiter filter plates and kept at $-20{ }^{\circ} \mathrm{C}$ until product analysis. Samples from reactions with mgLPMO10 alone were treated with an equal volume of a $0.36 \mathrm{~g} / \mathrm{L}$ mixture of Celluclast ${ }^{\circledR}$ and a $\beta$-glucosidase to convert oxidized 
cello-oligosaccharides to glucose and gluconic acid. Products were analyzed using UHPLC (see below).

\section{Product analysis with HPAEC-PAD}

Oxidized products were detected by high-performance anion-exchange chromatography (HPAEC) using a Dionex $^{\text {TM }}$ ICS5000 or ICS3000 (only for data in Fig. 2b) system (Thermo Scientific, Sunnyvale, CA) equipped with a disposable electrochemical gold electrode and a CarboPac PA1 $(2 \times 250 \mathrm{~mm})$ or a CarboPac PA200 $(3 \times 250 \mathrm{~mm})$ column (Dionex, Sunnyvale, CA, USA) operated with $0.1 \mathrm{M} \mathrm{NaOH}$ (eluent A) at a column temperature of $30{ }^{\circ} \mathrm{C}[60]$ and a flow rate of $0.25 \mathrm{ml} / \mathrm{min}$ or $0.5 \mathrm{ml} / \mathrm{min}$ for the PA 1 column and PA200 column, respectively. A multistep linear gradient with increasing amounts of eluent $\mathrm{B}(0.1 \mathrm{M} \mathrm{NaOH}+1 \mathrm{M} \mathrm{NaOAc})$ was used to elute the products. For the PA1 column the gradient was: $0-10 \% \mathrm{~B}$ over $10 \mathrm{~min} ; 10-18 \% \mathrm{~B}$ over $10 \mathrm{~min} ; 18-30 \%$ B over $1 \mathrm{~min} ; 30-100 \%$ B over $1 \mathrm{~min}$; $100-0 \%$ B over $0.1 \mathrm{~min}$; 0\% B (reconditioning) for $13.9 \mathrm{~min}$. For the PA200 column the gradient was: $0-10 \%$ B over 5 min; $10-18 \%$ B over 5 min; $18-30 \%$ B over $0.5 \mathrm{~min}$; $30-100 \%$ B over $0.5 \mathrm{~min} ; 100-0 \%$ B over $0.05 \mathrm{~min}$; 0\% B (reconditioning) for $6.95 \mathrm{~min}$. The gradient used for the ICS3000 system (PA1 column) was: $0-10 \%$ B over $10 \mathrm{~min} ; 10-30 \%$ B over $25 \mathrm{~min} ; 30-100 \%$ B over 5 min; $100-0 \%$ B over 1 min; 0\% B (reconditioning) for $9 \mathrm{~min}$. Data collection and analysis were carried out with the Chromeleon 7.0 software. Cellobiose (Sigma Aldrich) and cellotriose (Megazyme, Bray, Ireland) were used as substrates for production of C1-oxidized standards, i.e., cellobionic acid (GlcGlc1A) and cellotrionic acid $\left(\mathrm{Glc}_{2} \mathrm{Glc} 1 \mathrm{~A}\right)$, respectively, by treatment with cellobiose dehydrogenase from Myriococcum thermophilum ( $\mathrm{MtCDH}$ ) [61].

Native ( Glc $_{1-6}$ ) and oxidized (GlcGlc1A and Glc Glc1A) cello-oligosaccharides resulting from reactions with CBHs were analyzed using the same HPAEC system and the same eluents as described above, with a CarboPac PA200 column. The gradient was: $0-5.5 \% \mathrm{~B}$ over $3 \mathrm{~min}$; 5.5-15\% B over 6 min; $15-100 \%$ B over 11 min; $100-0 \%$ B over $0.1 \mathrm{~min}$; 0\% B (reconditioning) for $5.9 \mathrm{~min}$.

\section{Product analysis with UHPLC}

Quantification of glucose resulting from reactions with the Celluclast ${ }^{\circledR}$ enzyme cocktail was achieved using a Dionex Ultimate 3000 UHPLC system (Dionex, Sunnyvale, CA, USA) equipped with a Rezex ROA-Organic Acid $\mathrm{H}+(8 \%), 300 \times 7.8 \mathrm{~mm}$ analytical column and a SecureGuard Carbo-H $+4 \times 3.0 \mathrm{~mm}$ guard column (Phenomenex, Torrance, CA, USA) operated at $65^{\circ} \mathrm{C}$. Sample components were eluted isocratically over $22 \mathrm{~min}$ using
$5 \mathrm{mM}$ sulfuric acid as mobile phase with a flow rate of $0.6 \mathrm{~mL} / \mathrm{min}$. Products were detected using a refractive index (RI) detector 101 (Shodex, Tokyo, Japan) and data collection and analysis were carried out with the Chromeleon 7.0 software.

\section{MALDI-ToF product analysis}

Products in reaction supernatants were assayed qualitatively using a matrix-assisted laser desorption/ionization time-of-flight (MALDI-ToF) UltrafleXtreme mass spectrometer (Bruker Daltonics GmbH, Bremen, Germany) equipped with a Nitrogen 337-nm laser. Reaction mixtures $(1 \mu \mathrm{L})$ were applied to an MTP 384 ground steel target plate TF (Bruker Daltonics) and mixed with $2 \mu \mathrm{L}$ of $9 \mathrm{mg} / \mathrm{ml}$ of 2,5-dihydroxybenzoic acid dissolved in 30\% acetonitrile, followed by air-drying. Data collection and analysis were carried out using the Bruker FlexAnalysis software.

\section{Acknowledgements \\ We thank Phillip B. Pope and Alasdair K. Mackenzie for help in metagen- ome mining. We thank Novozymes for kindly providing Celluclast ${ }^{\circledR}$ and the $\beta$-glucosidase.}

\section{Authors' contributions \\ VGHE, GVK and ZF conceived the study. LF, ZF and VGHE supervised the work. TRT, MSJ, ZF and LF performed experiments. All authors interpreted data. MSJ and TRT wrote the initial draft. VGHE and ZF managed the writing process. \\ All authors contributed to producing the final version of the manuscript. All authors read and approved the final manuscript.}

\section{Funding}

This work was supported by Grants 221568 ("NorZymeD") and 268002 ("Enzymes4Fuels") from the Research Council of Norway and the Novo Nordisk Foundation (Grant NNF18OC0055736).

\section{Availability of data and materials}

All appropriate data for this study have been included in the manuscript.

Ethics approval and consent to participate

Not applicable.

Consent for publication

Not applicable.

Competing interests

The authors declare no competing interests.

Received: 21 August 2020 Accepted: 16 November 2020

Published online: 30 November 2020

\section{References}

1. Pauly M, Keegstra K. Cell-wall carbohydrates and their modification as a resource for biofuels. Plant J. 2008;54(4):559-68.

2. Klemm D, Heublein B, Fink H-P, Bohn A. Cellulose: Fascinating biopolymer and sustainable raw material. Angew Chem Int Ed. 2005;44(22):3358-93.

3. Duchesne LC, Larson DW. Cellulose and the evolution of plant life. Bioscience. 1989;39(4):238-41.

4. Somerville C, Bauer S, Brininstool G, Facette M, Hamann T, Milne J, et al. Toward a systems approach to understanding plant cell walls. Science. 2004;306(5705):2206-11. 
5. Merino ST, Cherry J. Progress and challenges in enzyme development for biomass utilization. In: Olsson L, editor. Biofuels. Advances in biochemical engineering/biotechnology. Berlin, Heidelberg: Springer; 2007. p. 95-120.

6. Harris PV, Xu F, Kreel NE, Kang C, Fukuyama S. New enzyme insights drive advances in commercial ethanol production. Curr Opin Chem Biol. 2014;19:162-70.

7. Davies G, Henrissat B. Structures and mechanisms of glycosyl hydrolases. Structure. 1995;3(9):853-9.

8. Horn SJ, Vaaje-Kolstad G, Westereng B, Eijsink VGH. Novel enzymes for the degradation of cellulose. Biotechnol Biofuels. 2012;5:45.

9. Vaaje-Kolstad G, Westereng B, Horn SJ, Liu Z, Zhai H, Sørlie M, et al. An oxidative enzyme boosting the enzymatic conversion of recalcitrant polysaccharides. Science. 2010;330(6001):219-22.

10. Chylenski P, Bissaro B, Sørlie M, Røhr AK, Várnai A, Horn SJ, et al. Lytic polysaccharide monooxygenases in enzymatic processing of lignocellulosic biomass. ACS Catalysis. 2019;9(6):4970-91.

11. Eibinger M, Ganner T, Bubner P, Rošker S, Kracher D, Haltrich D, et al. Cellulose surface degradation by a lytic polysaccharide monooxygenase and its effect on cellulase hydrolytic efficiency. J Biol Chem. 2014;289(52):35929-38.

12. Johansen KS. Lytic polysaccharide monooxygenases: The microbial power tool for lignocellulose degradation. Trends Plant Sci. 2016;21(11):926-36.

13. Müller G, Chylenski P, Bissaro B, Eijsink VGH, Horn SJ. The impact of hydrogen peroxide supply on LPMO activity and overall saccharification efficiency of a commercial cellulase cocktail. Biotechnol Biofuels. 2018;11(1):209.

14. Levasseur A, Drula E, Lombard V, Coutinho PM, Henrissat B. Expansion of the enzymatic repertoire of the CAZy database to integrate auxiliary redox enzymes. Biotechnol Biofuels. 2013;6(1):41.

15. Tandrup T, Frandsen KEH, Johansen KS, Berrin J-G, Lo LL. Recent insights into lytic polysaccharide monooxygenases (LPMOS). Biochem Soc Trans. 2018:46(6):1431-47.

16. Phillips CM, Beeson WT IV, Cate JH, Marletta MA. Cellobiose dehydrogenase and a copper-dependent polysaccharide monooxygenase potentiate cellulose degradation by Neurospora crassa. ACS Chem Biol. 2011;6(12):1399-406.

17. Quinlan RJ, Sweeney MD, Leggio LL, Otten H, Poulsen J-CN, Johansen $\mathrm{KS}$, et al. Insights into the oxidative degradation of cellulose by a copper metalloenzyme that exploits biomass components. Proc Natl Acad Sci. 2011;108(37):15079-84.

18. Isaksen T, Westereng B, Aachmann FL, Agger JW, Kracher D, Kittl R, et al. A C4-oxidizing lytic polysaccharide monooxygenase cleaving both cellulose and cello-oligosaccharides. J Biol Chem. 2014;289(5):2632-42.

19. Courtade G, Forsberg Z, Heggset EB, Eijsink VGH, Aachmann FL. The carbohydrate-binding module and linker of a modular lytic polysaccharide monooxygenase promote localized cellulose oxidation. J Biol Chem. 2018;293(34):13006-15.

20. Bissaro B, Røhr AK, Muller G, Chylenski P, Skaugen M, Forsberg Z, et al. Oxidative cleavage of polysaccharides by monocopper enzymes depends on $\mathrm{H}_{2} \mathrm{O}_{2}$. Nat Chem Biol. 2017;13(10):1123-8.

21. Loose JSM, Arntzen MØ, Bissaro B, Ludwig R, Eijsink VGH, Vaaje-Kolstad G. Multipoint precision binding of substrate protects lytic polysaccharide monooxygenases from self-destructive off-pathway processes. Biochemistry. 2018;57(28):4114-24.

22. Eijsink VGH, Petrovic D, Forsberg Z, Mekasha S, Røhr ÅK, Várnai A, et al. On the functional characterization of lytic polysaccharide monooxygenases (LPMOs). Biotechnol Biofuels. 2019;12(1):58.

23. Beeson WT, Phillips CM, Cate JHD, Marletta MA. Oxidative cleavage of cellulose by fungal copper-dependent polysaccharide monooxygenases. J Am Chem Soc. 2012;134(2):890-2.

24. Kjaergaard CH, Qayyum MF, Wong SD, Xu F, Hemsworth GR, Walton DJ, et al. Spectroscopic and computational insight into the activation of $\mathrm{O}_{2}$ by the mononuclear $\mathrm{Cu}$ center in polysaccharide monooxygenases. Proc Natl Acad Sci. 2014;111(24):8797-802.

25. Kuusk S, Bissaro B, Kuusk P, Forsberg Z, Eijsink VGH, Sørlie M, et al. Kinetics of $\mathrm{H}_{2} \mathrm{O}_{2}$-driven degradation of chitin by a bacterial lytic polysaccharide monooxygenase. J Biol Chem. 2018;293(2):523-31.

26. Hangasky JA, lavarone AT, Marletta MA. Reactivity of $\mathrm{O}_{2}$ versus $\mathrm{H}_{2} \mathrm{O}_{2}$ with polysaccharide monooxygenases. Proc Natl Acad Sci. 2018;115(19):4915-20.
27. Bissaro B, Kommedal E, Røhr ÅK, Eijsink VGH. Controlled depolymerization of cellulose by light-driven lytic polysaccharide oxygenases. Nat commun. 2020;11(1):1-12.

28. Filandr F, Man P, Halada P, Chang H, Ludwig R, Kracher D. The $\mathrm{H}_{2} \mathrm{O}_{2}$-dependent activity of a fungal lytic polysaccharide monooxygenase investigated with a turbidimetric assay. Biotechnol Biofuels. 2020;13(1):37.

29. Jones SM, Transue WJ, Meier KK, Kelemen B, Solomon El. Kinetic analysis of amino acid radicals formed in $\mathrm{H}_{2} \mathrm{O}_{2}$-driven Cul LPMO reoxidation implicates dominant homolytic reactivity. Proc Natl Acad Sci. 2020;117(22):11916-22.

30. Kittl R, Kracher D, Burgstaller D, Haltrich D, Ludwig R. Production of four Neurospora crassa lytic polysaccharide monooxygenases in Pichia pastoris monitored by a fluorimetric assay. Biotechnol Biofuels. 2012;5(1):79.

31. Forsberg Z, Sørlie M, Petrović D, Courtade G, Aachmann FL, Vaaje-Kolstad $\mathrm{G}$, et al. Polysaccharide degradation by lytic polysaccharide monooxygenases. Curr Opin Struct Biol. 2019;59:54-64.

32. Haki G, Rakshit S. Developments in industrially important thermostable enzymes: a review. Bioresour Technol. 2003;89(1):17-34.

33. Tanghe M, Danneels B, Last M, Beerens K, Stals I, Desmet T. Disulfide bridges as essential elements for the thermostability of lytic polysaccharide monooxygenase LPMO10C from Streptomyces coelicolor. Protein Eng Des Sel. 2017;30(5):401-8.

34. Lo Leggio L, Weihe CD, Poulsen J-CN, Sweeney M, Rasmussen F, Lin J, et al. Structure of a lytic polysaccharide monooxygenase from Aspergillus fumigatus and an engineered thermostable variant. Carbohydr Res. 2018:469:55-9.

35. Simmons CW, Reddy AP, D'haeseleer P, Khudyakov J, Billis K, Pati A, et al. Metatranscriptomic analysis of lignocellulolytic microbial communities involved in high-solids decomposition of rice straw. Biotechnol Biofuels. 2014;7(1):495.

36. Forsberg Z, Mackenzie AK, Sørlie M, Røhr ÅK, Helland R, Arvai AS, et al. Structural and functional characterization of a conserved pair of bacterial cellulose-oxidizing lytic polysaccharide monooxygenases. Proc Natl Acad Sci. 2014;111(23):8446-51.

37. Forsberg Z, Vaaje-Kolstad G, Westereng B, Bunæs AC, Stenstrøm Y, MacKenzie A, et al. Cleavage of cellulose by a CBM33 protein. Protein Sci. 2011;20(9):1479-83.

38. Jensen MS, Klinkenberg G, Bissaro B, Chylenski P, Vaaje-Kolstad G, Kvitvang $\mathrm{HF}$, et al. Engineering chitinolytic activity into a cellulose-active lytic polysaccharide monooxygenase provides insights into substrate specificity. J Biol Chem. 2019;294(50):19349-64.

39. Müller G, Várnai A, Johansen KS, Eijsink VGH, Horn SJ. Harnessing the potential of LPMO-containing cellulase cocktails poses new demands on processing conditions. Biotechnol Biofuels. 2015;8(1):187.

40. Irwin DC, Zhang S, Wilson DB. Cloning, expression and characterization of a family 48 exocellulase, Cel48A, from Thermobifida fusca. Eur J Biochem. 2000;267(16):4988-97.

41. Zhang $\mathrm{S}$, Lao G, Wilson DB. Characterization of a Thermomonospora fusca exocellulase. Biochemistry. 1995;34(10):3386-95.

42. Wu M, Bu L, Vuong TV, Wilson DB, Crowley MF, Sandgren M, et al. Loop motions important to product expulsion in the Thermobifida fusca glycoside hydrolase family 6 cellobiohydrolase from structural and computational studies. J Biol Chem. 2013;288(46):33107-17.

43. Horn SJ, Sørlie M, Vårum KM, Väljamäe P, Eijsink VGH. Measuring processivity. Methods Enzymol. 2012;510:69-95.

44. Kracher D, Andlar M, Furtmüller PG, Ludwig R. Active-site copper reduction promotes substrate binding of fungal lytic polysaccharide monooxygenase and reduces stability. J Biol Chem. 2018;293(5):1676-87.

45. Sugimoto H, Nakajima Y, Motoyama A, Katagiri E, Watanabe T, Suzuki K. Unfolding of CBP21, a lytic polysaccharide monooxygenase, without dissociation of its copper ion cofactor. Biopolymers. 2020;111(1):e23339.

46. Vaaje-Kolstad G, Bohle LA, Gaseidnes S, Dalhus B, Bjoras M, Mathiesen G, et al. Characterization of the chitinolytic machinery of Enterococcus faecalis V583 and high-resolution structure of its oxidative CBM33 enzyme. J Mol Biol. 2012;416(2):239-54.

47. Hemsworth GR, Taylor EJ, Kim RQ, Gregory RC, Lewis SJ, Turkenburg JP, et al. The copper active site of CBM33 polysaccharide oxygenases. J Am Chem Soc. 2013;135(16):6069-77.

48. Singh RK, Blossom BM, Russo DA, van Oort B, Croce R, Jensen $P E$, et al. Thermal unfolding and refolding of a lytic 
polysaccharide monooxygenase from Thermoascus aurantiacus. RSC Adv. 2019;9(51):29734-42.

49. Frommhagen $M$, Westphal AH, Hilgers R, Koetsier MJ, Hinz SWA, Visser J, et al. Quantification of the catalytic performance of C1-cellulose-specific Iytic polysaccharide monooxygenases. Appl Microbiol Biotechnol. 2018;102(3):1281-95.

50. Semenova MV, Gusakov AV, Telitsin VD, Rozhkova AM, Kondratyeva EG, Sinitsyn AP. Purification and characterization of two forms of the homologously expressed lytic polysaccharide monooxygenase (PVLPMO9A) from Penicillium verruculosum. Biochim Biophys Acta. 2020;1868(1):140297.

51. Zhou H, Li T, Yu Z, Ju J, Zhang H, Tan H, et al. A lytic polysaccharide monooxygenase from Myceliophthora thermophila and its synergism with cellobiohydrolases in cellulose hydrolysis. Int J Biol Macromol. 2019;139:570-6.

52. Tokin R, Ipsen JØ, Westh P, Johansen KS. The synergy between LPMOs and cellulases in enzymatic saccharification of cellulose is both enzyme-and substrate-dependent. Biotechnol Lett. 2020;42:1975-84.

53. Hu J, Arantes V, Pribowo A, Gourlay K, Saddler JN. Substrate factors that influence the synergistic interaction of AA9 and cellulases during the enzymatic hydrolysis of biomass. Energy Environ Sci. 2014;7(7):2308-15.

54. Reddy AP, Simmons CW, D'haeseleer P, Khudyakov J, Burd H, Hadi M, et al. Discovery of microorganisms and enzymes involved in high-solids decomposition of rice straw using metagenomic analyses. PLOS ONE. 2013:8(10):e77985.

55. Manoil C, Beckwith J. A genetic approach to analyzing membrane protein topology. Science. 1986;233(4771):1403-8.

56. Jensen MS, Fredriksen L, Mackenzie AK, Pope PB, Leiros I, Chylenski P, et al. Discovery and characterization of a thermostable two-domain
GH6 endoglucanase from a compost metagenome. PLoS ONE. 2018;13(5):e0197862.

57. Wood TM. Preparation of crystalline, amorphous, and dyed cellulase substrates. In:Wood WA, Kellogg ST, editors. Methods Enzymol. Biomass Part A: Cellulose and Hemicellulose, vol. 160. New York: Academic Press; 1988. p. 19-25.

58. Bronnenmeier K, Rücknagel KP, Staudenbauer WL. Purification and properties of a novel type of exo-1, 4- $\beta$-glucanase (Avicelase II) from the cellulolytic thermophile Clostridium stercorarium. Eur J Biochem. 1991;200(2):379-85

59. Morag E, Halevy I, Bayer EA, Lamed R. Isolation and properties of a major cellobiohydrolase from the cellulosome of Clostridium thermocellum. J Bacteriol. 1991;173(13):4155-62.

60. Westereng B, Agger JW, Horn SJ, Vaaje-Kolstad G, Aachmann FL, Stenstrøm YH, et al. Efficient separation of oxidized cello-oligosaccharides generated by cellulose degrading lytic polysaccharide monooxygenases. J Chromatogr A. 2013;1271(1):144-52.

61. Zámocký M, Schümann C, Sygmund C, O'Callaghan J, Dobson AD, Ludwig R, et al. Cloning, sequence analysis and heterologous expression in Pichia pastoris of a gene encoding a thermostable cellobiose dehydrogenase from Myriococcum thermophilum. Protein Expr Purif. 2008;59(2):258-65.

\section{Publisher's Note}

Springer Nature remains neutral with regard to jurisdictional claims in published maps and institutional affiliations.
Ready to submit your research? Choose BMC and benefit from:

- fast, convenient online submission

- thorough peer review by experienced researchers in your field

- rapid publication on acceptance

- support for research data, including large and complex data types

- gold Open Access which fosters wider collaboration and increased citations

- maximum visibility for your research: over 100M website views per year

At BMC, research is always in progress.

Learn more biomedcentral.com/submissions 